\title{
Patterns of major photosynthetic pigments in freshwater algae. 1. Cyanoprokaryota, Rhodophyta and Cryptophyta
}

\author{
M. Schagerl ${ }^{1 *}$, Karl Donabaum² \\ ${ }^{1}$ Institute of Ecology and Conservation Biology, University of Vienna, Althanstraße 14, A-1090 Vienna, Austria. \\ ${ }^{2}$ Donabaum \& Wolfram OEG, Zentagasse 14, A-1050 Vienna, Austria.
}

\begin{abstract}
This study investigated major pigment patterns of 8 cyanoprokaryota, 2 rhodophytes and 2 cryptomonads isolated from freshwater ecosystems. Analysis was done by means of HPLC. The method, historically adapted to marine phytoplankton, was modified to accommodate limnic algae. Quantitative results obtained in this study can be used for phytoplankton quantification techniques based on pigment patterns. Compared to marine strains, the studied freshwater cyanoprokaryote strains reveal a more complex pigment pattern, including myxoxanthophyll, canthaxanthin and echinenone. Cryptophyta possess the two acetylenic class-specific marker compounds allo- and monadoxanthin, crocoxanthin was not detectable. Rhodophytes show a simple pigment pattern similar to marine species. Previous reports as to the existence of chlorophyll-d could not be confirmed (historical reports probably refer to an artefact of preparation). Besides methodological considerations, the phenomenon of complementary chromatic adaptation is discussed briefly.
\end{abstract}

Keywords : HPLC, freshwater algae, pigments, carotenoids, cyanoprokaryota, cyanobacteria, rhodophyta, cryptophyta.

\section{Introduction}

Besides ultrastructural and biochemical characteristics, thallus color, which is due to antenna pigments of the photosynthetic apparatus, is one of the major distinguishing criteria in the classification of algae, finding its reflection in the likes of cyanoprocaryota, rhodophyta, chlorophyta, xanthophyceae, chrysophyceae, or phaeophyceae. The majority of past studies on algal pigments, however, have dealt almost exclusively with abundant marine taxa of the coccolithophorids (prymnesiophyceae - haptophyta), bacillariophyceae (heterokontophyta), dinophyta or benthic macroalgae (eg. Gieskes \& Kraay 1983, Mantoura \& Llewellyn 1983, Wright \& Shearer 1984, Gieskes \& Kraay 1986a, b, Klein \& Sournia 1987, Roy 1989, Veldhuis \& Kraay 1990, Kohata \& Watanabe 1991, Wright et al 1991, Tester et al. 1995, Jeffrey et al. 1997, Hiraoka et al. 1998, Meyer-Harms \& Pollehne 1998, Schofield et al.

\footnotetext{
* corresponding author : michael.schagerl@univie.ac.at
}

1998). As a consequence, detailed information about typical limnic taxa is still scarce, to date (e.g. Millie et al. 1990, Senge \& Senger 1991, Wilhelm et al. 1991, Woitke et al. 1996, Nicklisch \& Woitke 1999).

Some twenty years ago, pigment analysis relied on paper- and thin layer chromatography, (e.g. Hager \& Stransky 1970a, b, Vesk \& Jeffrey 1977, Hallegraeff 1981, Hallegraeff \& Jeffrey 1985, Suzuki \& Fujita 1986, Jeffrey \& Wright 1987), whereas high performance liquid chromatography (HPLC) has become the major tool during the past 15 years. Its high resolution performance, accuracy and reproducibility of results, as well as short analyzing times (approx. $30 \mathrm{~min}$.) and the need of only small sample volumes (in the $\mu$ l-range) all speak in favour of this method. Shortly after becoming available, reversed-phase (RP) colums with excellent separating properties were employed for pigment analysis. Due to their apolarity, they proofed to be ideally suited for analysis of fatty substances. Another advantage of RP-HPLC is the inert column environment, as stationary phase silanol groups, to a great extent, are bound by silanisation with octyl- and octadecylsilanes. Chlorophylls (chl-s) and carotenoids thus 
remain stable during separation and detection, there is no destruction of reactive conjugated double bindings by acid, oxygen or light. The studies by Mantoura \& Llewellyn (1983), Wright \& Shearer (1984) and Wright et al. (1991) are milestones in pigment analysis (review in Jeffrey et al. 1997).

In addition to the lipophilic pigments investigated in this study, cyanoprocaryota, rhodo- and cryptophyta also contain hydrophilic phycobiliproteins (not entered in this study). In the cyanoprocaryota and rhodophytes these water-soluble pigments are concentrated in phycobilisomes, acting as highly efficient extrinsic light harvesting complexes to the photosystem II (Glazer 1982, 1984, Cogdell 1988, Siefermann-Harms 1985, Hiller et al. 1991). Among the three groups, intrinsic light harvesting systems, so far, have been studied in the cryptophyta only, where they were found to consist of chls-a/c $\mathrm{c}_{2}$ and alloxanthin.

In the last decade, class-specific pigment markers have been established for phytoplankton quantification to an increasing degree (eg. Wilhelm et al. 1991, Descy \& MÈtens 1996, Mackey et al. 1996, Roy et al. 1996, Jeffrey et al. 1997, Latasa et al. 1997, Goericke \& Montoya 1998, Schmid et al. 1998, Steinman et al. 1998). This method could be employed with high prospects of success particularly for monitoring lake systems. Besides direct relation of specific carotenoids to algal biomass, pigment/chl-a ratios on basis of total chl-a are commonly used for estimating phytoplankton composition. From a physiological point of view the latter option sounds more promising because acclimatisation to different light and nutrient supply is relativized by division by chl-a. However, some studies have shown that a direct conversion from carotenoids to algal biomass might be more accurate (Strom \& Welschmeyer 1991, Descy \& Métens 1996, Schmid et al. 1998). New attempts on algal quantification have also been made using multivariate statistics like multiple linear regression (eg. Woitke et al. 1996) or factor analysis (Mackey et al. 1996, Wright et al. 1996). For these approaches, basic data sets of carotenoid contents are needed, which are obtained from pure cultures. Some quantitative pigment data are contributed in the present study.

As previously mentioned, to date, most studies of algal pigments have concentrated on marine taxa. In contrast, this study focused on pigment patterns of common freshwater species, in an attempt to help find an answer to the question of whether, or not, major pigment differences exist between limnic and marine species. This study will also provide a basis for systematic, physiological and ecological investigations.

\section{Materials and methods}

Organisms (see Table 1) were obtained from the culture collection of algae at the Institute of Ecology and Conservation Biology at the University of Vienna (Kusel-Fetzmann \& Schagerl 1992). The unialgal, nonaxenic batch-clones were cultured at $20{ }^{\circ} \mathrm{C}$. Growth was established using a light:dark regime of $14 \mathrm{~h}$ white light $\left(30 \mu \mathrm{mol}\right.$ photons $\left.\mathrm{m}^{-2} \mathrm{~s}^{-1}\right)$ and $10 \mathrm{~h}$ darkness. Several clones were grown in parallel cultures. Rhodophytes were procured directly from the Fischa river or from aquaria after careful microscopical examination which excluded attached algae in higher numbers. To test the variability of carotenoids per unit chl-a, data sets of cyanoprokaryotic continuous cultures with varying nutrient supply (original $\mathrm{Chu}_{10}$ according to $\mathrm{Ku}$ sel-Fetzmann \& Schagerl 1992 and modifications like $0.5 \mathrm{~N}, 5 \mathrm{~N}+0.5 \mathrm{P}$ and $10 \mathrm{~N}$ on a weight basis) at different light conditions were added $\left(150 \mu \mathrm{E} \mathrm{m}^{-2} \mathrm{~s}^{-1}\right.$ and $60 \mu \mathrm{E} \mathrm{m}^{-2} \mathrm{~s}^{-1}$, respectively). Details are given in Donabaum (1992).

Prior to extraction, algal suspensions were harvested on Whatman $\mathrm{GF} / \mathrm{C}$ filters and stored at $-30{ }^{\circ} \mathrm{C}$ at least overnight for breaking the cell walls. Extraction was carried out by using $90 \%$ cold acetone. Filters were immersed in $5 \mathrm{ml} 90 \%$ acetone and ground for 30 seconds using a Potter-homogenizer (Elfechiem). The suspensions were transferred to centrifuge tubes, and the pigments stored at $2{ }^{\circ} \mathrm{C}$ for 12 hours to achieve optimal extraction (Gätz 1990, Jeffrey et al. 1997). After centrifugation for $10 \mathrm{~min}$ at $3000 \mathrm{rpm}$ (Sigma-centrifuge) the supernatant was injectetd into the HPLC system. Extraction took place in dim light to minimize formation of artificial cis-trans-isomeres.

The HPLC-system (Merck-Hitachi) employed consisted of an autosampler (AS-4000), a gradientpump (L-6200) and an UV-VIS-detector (L-4250). 10 minutes prior to injection, the extract was diluted with ionpairing reagent TBAA $=3+1$ (volume/volume; Table 2). Chromatography was carried out on a RP-column (Merck Superspher rp-18 250/4 ; precolumn : Merck Lichrospher rp-18 endcapped). Solvents used were HPLC grade (Table 2). Pigment extracts were separated by use of a ternary low pressure gradient program (Table 2).

Peaks were detected at $440 \mathrm{~nm}$ and identified by cochromatography with authentic standards (DHI Bioproducts, Denmark), their specific absorption maxima, and by comparison with values from the literature (Foppen 1971 ; Mantoura and Llewellyn 1983, Wright and Shearer 1984, Wright et al. 1991, Jeffrey et al. 1997). D-6000 HPLC-manager software (Merck) was 
employed for analyses, nomenclature of pigments followed trivial names. Peak quantification of major pigments with calibration curves (DHI Bioproducts, Denmark) : chl's-a and -c, alloxanthin, echinenone, myxoxanthophyll, $\alpha$ - and $\beta$-carotene. For lutein, zeaand monadoxanthin the calibration curve of $\beta$-carotene was used and for canthaxanthin that of echinenone, respectively.

Linear regression analyses and analyses of variance (ANOVA) were performed by SPSS 9.0.1. (SPSS inc.).

\section{Results}

\section{Cyanoprokaryota}

Detected pigments : chl-a and derivatives, «cyanopeaks» I and II, a compound similar to myxoxanthophyll, myxoxanthophyll, nostoxanthin, caloxanthin, zeaxanthin, canthaxanthin, echinenone, $\beta$-carotene, cis-ß-carotene.

Besides chl-a, all investigated cyanoprocaryotic strains revealed larger quantities of myxoxanthophyll, zeaxanthin, echinenone, and B-carotene (Figs. 1, 2,

Table 1. Cultures used in this study (media composition according to Kusel-Fetzmann \& Schagerl 1992).

\begin{tabular}{|c|c|c|c|}
\hline Species & Strain & Isolated from & Medium \\
\hline \multicolumn{4}{|l|}{ Cyanoprokaryota } \\
\hline Anabaenopsis elekini Mill. & 01027 & Lake Neusiedler See & $\mathrm{F}$ \\
\hline Aphanizomenon flexuosum Kom. et Kovacik & 01033 & backwater in Vienna & $\mathrm{FE}$ \\
\hline Chroococcus minutus (Kütz.) Näg. & 01017 & Lake Neusiedler See & $\mathrm{F}$ \\
\hline Cylindrospermum $\mathrm{sp}$. & 01016 & Lake Neusiedler See & $\mathrm{DN}$ \\
\hline Microcystis aeruginosa Kütz. & 01001 & Lake Neusiedler See & $\mathrm{F}$ \\
\hline Microcystis flos-aquae (Wittr.) Kirchn. & 01004 & Lake Neusiedler See & $\mathrm{F}$ \\
\hline Microcystis wesenbergii Komarek & 01024 & Lake Neusiedler See & $\mathrm{F}$ \\
\hline Nostoc sp. & 01010 & Lake Neusiedler See & $\mathrm{D}$ \\
\hline \multicolumn{4}{|l|}{ Rhodophyta } \\
\hline Audouinella sp. & - & fresh material, aquarium & - \\
\hline Batrachospermum moniliforme (Roth.) Sirodot & - & fresh material, river Fischa & - \\
\hline \multicolumn{4}{|l|}{ Cryptophyta } \\
\hline Cryptomonas sp. & 09001 & Museumsteich near Neusiedl & MK \\
\hline Cryptomonas rostratiformis Skuja & 09004 & backwater in Vienna & MK \\
\hline
\end{tabular}

Table 2. Ternary low pressure gradient program applied in this investigation. Solvent A : $100 \%$ Acetonitrile (HPLC-grade, MERCK) ; Solvent B : distilled water : TBAA $=4+1(\mathrm{vol} / \mathrm{vol}) ;$ Solvent $\mathrm{C}: 100 \%$ acetone $: 100 \%$ acetonitrile $=2+1(\mathrm{vol} / \mathrm{vol}$; HPLC-grade, MERCK). TBAA preparation : dissolve $77 \mathrm{~g}$ ammonia-acetate and 30 $\mathrm{ml} 0.5 \mathrm{M}$ tetrabutylammonia-hydroxyde in $1000 \mathrm{ml}$ distilled water.

\begin{tabular}{ccccc}
\hline Time (min) & \% A & \% B & \%C & Flow $\left(\mathbf{m l ~ m i n}^{-\mathbf{1}}\right)$ \\
\hline 0 & 50 & 50 & 0 & 1 \\
5 & 70 & 30 & 0 & 1.5 \\
18 & 20 & 10 & 70 & 1.5 \\
23 & 0 & 0 & 100 & 1.5 \\
33 & 0 & 0 & 100 & 1 \\
35 & 50 & 50 & 0 & 1 \\
\hline
\end{tabular}



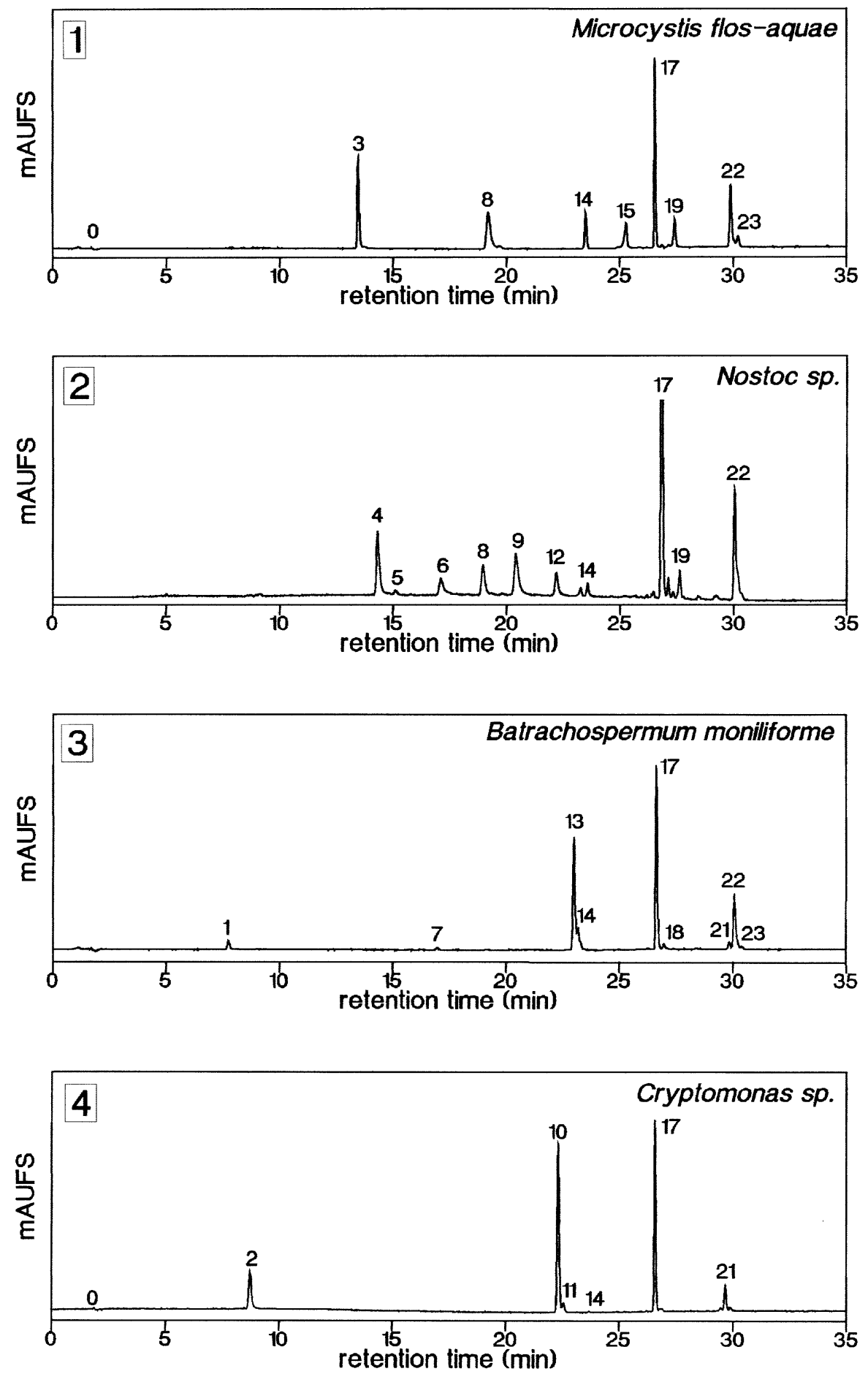

Fig. 1. 1. Chromatograms of the cyanobacteria Microcystis flos-aquae ; 2. Nostoc sp.; 3. The rhodophyte Batrachospermum moniliforme; 4 . The cryptophyte Cryptomonas sp.. Peak numbers according to table 3 . 

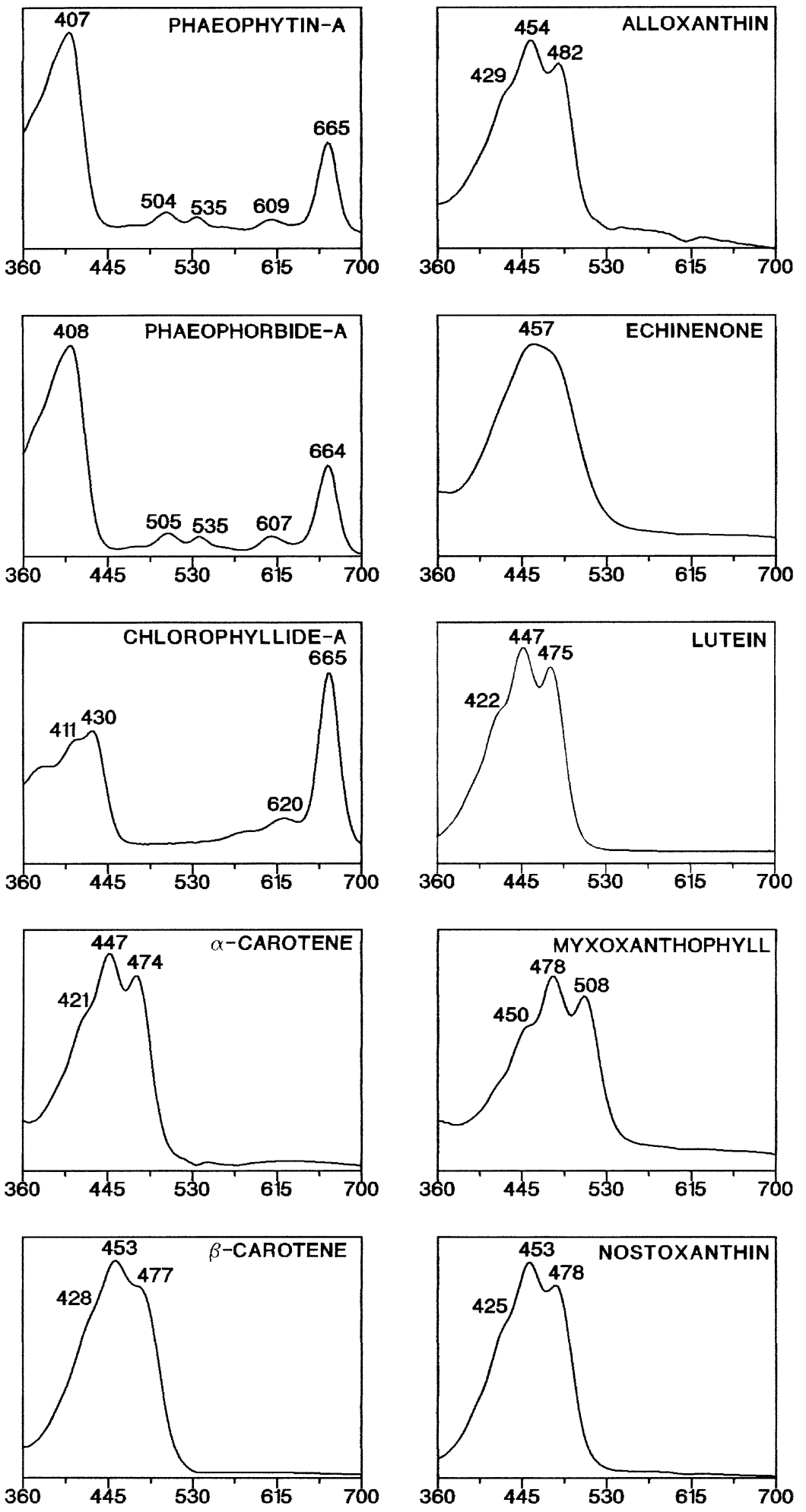

Fig. 2. Absorption spectra of chl-a degradation products and major carotenoids. 
Tables 4, 5). B-carotene showed largest amounts per chl-a (21\%), followed by myxoxanthophyll (17\%). Highest relation at different light and nutrient conditions were calculated between B-carotene and chl-a $\left(r^{2}=0.895\right)$. In all cultures, canthaxanthin eluted prior to chl-a, however, concentrations varied considerably $\left(\mathrm{r}^{2}=0.459, \mathrm{n}=66\right.$, Table 5). Nostoxanthin and caloxanthin were found exclusively in Nostoc sp. (Fig. 1), whilst other strains of the Nostocales apparently lack these pigments (Table 4). Myxoxanthophyll-like compounds were detected in Nostoc sp. and Aphanizomenon flexuosum, absorption maxima were similar to that of myxoxanthophyll (Table 3). In some of the blue-greens, two unidentified peaks were detected (numbers 3 and 4, Table 3 ; Anabaenopsis elenkinii, Aphanizomenon flexuosum, Chroococcus minutus, $\mathrm{Mi}$ crocystis flos-aquae, Nostoc sp.). These pigments exhibit typical carotenoid absorption spectra (maxima at $447 \mathrm{~nm}$ and $466 \mathrm{~nm}$ ), early elution hints at hydrophilic substituents.

\section{Rhodophyta}

Detected pigments were chl-a and derivatives, (neoxanthin), lutein, zeaxanthin, $\alpha$-carotene, $\beta$-carote-

Table 3. Retention times (Rt) and absorption maxima of pigments in the eluent; shoulders in brackets.

\begin{tabular}{|c|c|c|c|}
\hline Peak & Pigment & $\mathbf{R t}$ & Absorption maxima \\
\hline 0 & solvent front & 1,61 & \\
\hline 1 & chlorophyllide- $a$ & 8,01 & $(411), 430,620,665$ \\
\hline 2 & chls $c 1+c 2$ & 8,31 & $441,581,631$ \\
\hline 3 & „cyano-peak I“ & 13,60 & 447,466 \\
\hline 4 & „cyano-peak II“" & 14,07 & $464,(481)$ \\
\hline 5 & phaeophorbide- $a$ & 15,10 & $408,505,535,607,664$ \\
\hline 6 & myxoxanthophyll-like & 16,78 & $448,482,506$ \\
\hline 7 & neoxanthin & 16,86 & $(411), 437,466$ \\
\hline 8 & myxoxanthophyll & 18,46 & $(450), 478,508$ \\
\hline 9 & nostoxanthin & 20,22 & $(425), 453,478$ \\
\hline 10 & alloxanthin & 21,57 & $(429), 454,482$ \\
\hline 11 & monadoxanthin & 21,68 & $(428), 448,480$ \\
\hline 12 & caloxanthin & 21,92 & $(425), 453,478$ \\
\hline 13 & lutein & 22,98 & $(422), 447,475$ \\
\hline 14 & zeaxanthin & 23,30 & $(423), 454,478$ \\
\hline 15 & canthaxanthin & 24,48 & 456 \\
\hline 16 & chl- $a$ allomer & 26,28 & $(414), 428,615,662$ \\
\hline 17 & $\operatorname{chl} 1-a$ & 26,67 & $(408), 428,617,663$ \\
\hline 18 & chl- $a$ epimer & 26,96 & $(408), 429,617,662$ \\
\hline 19 & echinenone & 27,37 & 457 \\
\hline 20 & phaeophytin- $a$ & 28,83 & $407,504,535,609,665$ \\
\hline 21 & $\alpha$-carotene & 29,86 & $421,447,474$ \\
\hline 22 & $\beta$-carotene & 30,08 & $428,453,477$ \\
\hline 23 & cis- $\beta$-carotene & 30,38 & 448,475 \\
\hline
\end{tabular}




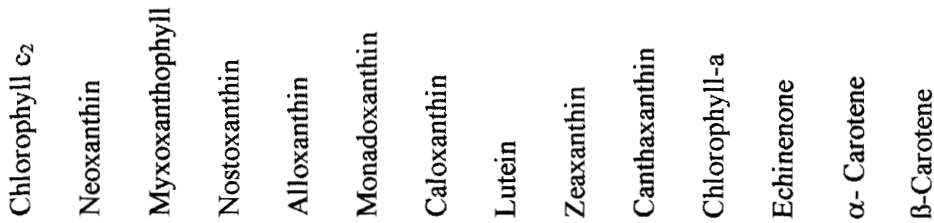

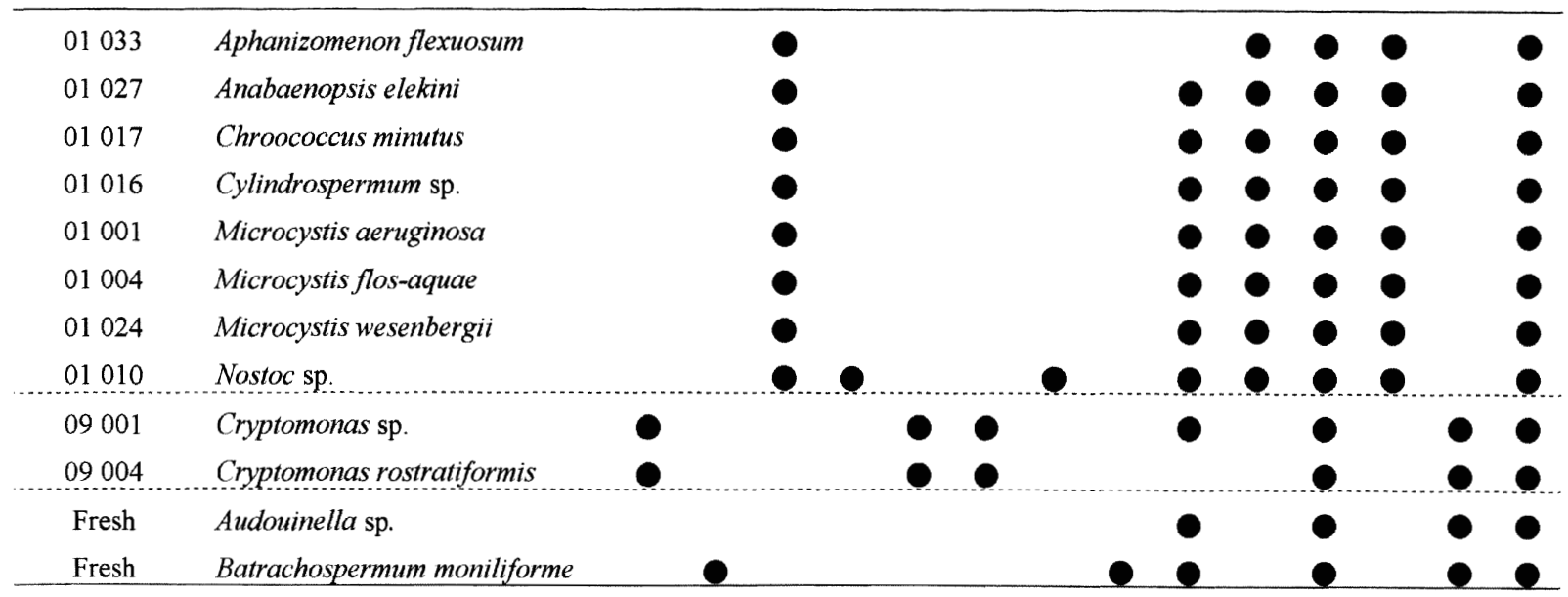

Table 5. Major pigments on basis of chl-a (\% pig ; weight/weight) obtained from linear regression and ANOVA,

CD...coefficient of determination, SE...standard error, df...degrees of freedom, sign...level of significance.

\begin{tabular}{lcccccc}
\hline & \% pig & CD & SE & df & F-value & sign \\
\hline Cyanoprokaryota & & & & & & \\
Myxoxanthophyll & 16.7 & 0.745 & 0.012 & 66 & 190 & $<0.001$ \\
Zeaxanthin & 8.5 & 0.688 & 0.007 & 66 & 143 & $<0.001$ \\
Canthaxanthin & 2.6 & 0.459 & 0.003 & 66 & 55 & $<0.001$ \\
Echinenone & 6.2 & 0.792 & 0.004 & 66 & 248 & $<0.001$ \\
B-carotene & 20.8 & 0.895 & 0.009 & 66 & 553 & $<0.001$ \\
\hline Cryptophyta & & & & & & \\
Chl c 2 & 7.3 & 0.980 & 0.004 & 8 & 346 & $<0.001$ \\
Alloxanthin & 25.7 & 0.869 & 0.038 & 8 & 47 & $<0.001$ \\
Monadoxanthin & 0.8 & 0.848 & 0.001 & 8 & 39 & $<0.001$ \\
$\alpha$-carotene & 5.3 & 0.953 & 0.004 & 8 & 142 & $<0.001$ \\
B-carotene & 1.1 & 0.912 & 0.001 & 8 & 73 & $<0.001$ \\
\hline Rhodophyta & & & & & & \\
Lutein & 22.9 & & & & & \\
Zeaxanthin & 2.5 & & & & &
\end{tabular}


ne, cis- $\beta$-carotene. Analyzed strains contained chl-a only, chl-d was absent (Fig. 1). Apart from small quantities of neoxanthin, the xanthophylls lutein and zeaxanthin, as well as $\alpha, \beta$ - and cis- $\beta$-carotene were found. Neoxanthin is probably an impurity of Batrachospermum moniliforme, which was collected from the field (Bjornland \& Aguilar-Martinez 1976, LiaaenJensen 1978).

\section{Cryptophyta}

Detected pigments were chls-c ${ }^{2}$, -a, alloxanthin, monadoxanthin, zeaxanthin, $\alpha$ - and $\beta$-carotene. In pigment extracts, chls-a and $-\mathrm{c}_{2}$ were identified. Alloxanthin was the most abundant carotenoid (around $26 \%$ per chl-a), but cultures also contained small quantities of monadoxanthin. Zeaxanthin, present in many algal groups, was detected only in traces (Fig. 1) ; $\alpha$-carotene dominated over $\beta$-carotene (Table 5).

\section{Discussion}

\section{Accommodation of the method}

Pigment analysis starts with sample concentration (Otsuki et al. 1987) and selection of an appropriate extracting agent (for important criteria see Jeffrey et al. 1997). In this study acetone, a common and efficient extraction solvent, was employed (eg. Mantoura \& Llewellyn 1983, Shioi et al. 1984, Bidigare et al. 1985, Kohata \& Watanabe 1988, 1989, Kohata \& Watanabe 1991, Wright et al. 1991, Descy \& Métens 1996, Latasa et al. 1997, Nicklisch \& Woitke 1999). Acetone is rated as being non-toxical, whereas highly efficient extracting agents, such as dimethyl sulfoxide or dimethyl formamide, are classified as being carcinogenic. Occasionally, alcohols like 2-propanol (Scholz \& Ballschmiter 1981), methanol (Kraay et al. 1992, Wright \& Shearer 1984), ethanol (Nusch 1980, Sartory 1985), or mixtures (Abaychi \& Riley 1979) are prefered to acetone. However, the potential extraction efficiency of individual solvents remains to be controversial. Comparing hot ethanol, cold methanol, and acetone, Jacobsen \& Rai (1990) observed inefficient extraction by acetone. Zapata \& Garrido (1991) found no differences in extraction efficiency between acetone and methanol. Jeffrey et al. (1997) recommended sonication in dimethyl formamide, but they did not favor this procedure for routine work because of the dimethyl formamide`s toxicity.

Another factor to be considered, are chemical reactions that might take place between the extracting agent and the sample compounds. Alcohols enhance the formation of chl derivatives (Hynninen \& Assandri 1973, Otsuki et al. 1987). Thus, methanol and ethanol, apparently, are involved in allomere formation.

The gradient program employed in this investigation had to aim at a high resolution, moderate use of solvents and short analyzing times. As in the case of extracting agents, solvents should stay as inert as possible considering the sample. For preparation of the mobile phase, chiefly methanol, acetonitrile, acetone, or ethylacetate, all diluted with distilled water, are in use. This study finally opted for a acetonitrile/acetone/water mixture, after pilot tests had revealed numerous decomposition products caused by the commonly used methanol gradient program (compare Scholz \& Ballschmiter 1981, Shioi et al. 1983). Also, resolution of the acetonitrile gradient is significantly higher, due to the lower viscosity of this mixture (Unger 1989, Kohata \& Watanabe 1991, Meyer 1999).

\section{Cyanoprokaryota}

The monocyclic carotenoid-glycoside myxoxanthophyll, typical of many freshwater cyanoprokaryota, apparently is a class specific pigment, since it has not been detected in eucaryotic algae to date (Weber \& Wettern 1980, Rowan 1989, Young \& Britton 1993, Jeffrey et al. 1997, Lee 1999). Another particularity of freshwater cyanobacteria are the primary cetocarotenoids canthaxanthine and echinenone (Healey 1968, Stransky \& Hager 1970, Hertzberg et al. 1971, Fiksdahl et al. 1983). The same cetocarotenoids have also been encountered in seasoned cultures of some chlorellales, however, exclusively functioning as secondary carotenoids concentrated either in droplets outside of the plastids, or within the cell wall in combination with sporopollenine (Britton 1988). During xanthophyll synthesis, cyanobacteria are not capable of $\varepsilon$-ring synthesis (Goodwin \& Britton 1988), thus lacking $\alpha$ carotene and lutein, whereas zeaxanthin, $\alpha$-carotene and cis- $\beta$-carotene are always present in this group. There are no light induced xanthophyll transformations in cyanoprocaryota (Stransky \& Hager 1970). Due to the lack of a violaxanthin cycle (synthesis of the epoxycarotenoids viola- and antheraxanthin has not yet been observed) cyanoprocaryota adjust quite slowly to intense illumination. Supersaturating light energy is probably dissipated by zeaxanthin, which has also been found in higher plants (Demmig-Adams 1989, 1990).

In Nostoc sp. and Aphanizomenon flexuosum a peak with absorption maxima similar to myxoxanthophyll was observed which is probably an isomere formation. 
In some strains two additional unidentifiable compounds were detected. These pigments exhibit typical carotenoid absorption spectra (maxima at 447nm and $466 \mathrm{~nm}$ ), early elution hints at hydrophilic substituents. Absorption maxima and the short retention time exclude the acyclic car otenoid oscillaxanthin as an explanation. The compounds possibly originated from the cell walls (Resch \& Gibson 1983) ; a definite identification would call for structural analysis.

Compared to marine organisms, all studied strains revealed much more complex pigment patterns. However, an exception that proves the rule is Trichodesmium showing small amounts of myxoxanthophyll (Carpenter et al. 1993, Mackey et al. 1996). Marine picoplanktonics (Synechococcus spp.), in particular, seem to exhibit a simple pattern containing zeaxanthin, B-carotene and chl-a (Guillard et al. 1985, Kana et. al. 1988, Mackey et al. 1996, Jeffrey et al. 1997), demonstrating why zeaxanthin acts as a chemotaxonomical marker in marine ecosystems (eg. Roy et al 1996, Latasa et al. 1997, Goericke 1998). For freshwater environments, where zeaxanthin - involved in the violaxanthin-cyclus is present in a number of classes, other tracers such as echinenone or myxoxanthophyll should be preferred. By dissipating surplus energy, zeaxanthin is an essential protective part of the photosynthetic apparatus. Depending on light intensity, varying amounts of zeaxanthin are to be expected, which is another reason why zeaxanthin is not suited as a marker pigment (Wilhelm et al. 1991). In Planktothrix agardhii (Gom.) Anagn. et Kom., Millie et al. (1990) showed a an increase in the relative abundances of myxoxanthophyll and zeaxanthin at higher light intensities, whilst chl-a, echinenone and $B$-carotene decreased. The same pattern of acclimatisation was observed by Rücker et al. (1995), who varied growth-limiting factors in three cyanobacterian species (Planktothrix agardhii, Limnothrix redekei (Van Goor) Meffert, Aphanizomenon gracile Lemm.).

The following two representative examples of Synechococcus and Limnothrix are pointing out that there still exists the basic necessity for detailed studies in pigment patterns and quantification, which may give some hints of taxonomic classification, too. By comparison of carotenoid pattern within Synechococcus, one will find only zeaxanthin and B-carotene (Kana et al. 1988, Mackey et al. 1996) or additionally echinenone (Woitke et al. 1996). In the freshwater species Synechococcus elongatus (Näg). Näg. three more carotenoids, namely calo-, nostoxanthin and myxoxanthophyll were observed by Stransky \& Hager (1970). Guillard et al. (1985) analyzed 4 different marine clones of Synechococcus, each of them holding a different carotenoid pattern. In L. redeckei, echinenone generally was absent in investigations made by Rücker et al. (1995), but was verified by Nicklisch \& Woitke (1999).

Because zeaxanthin is used for an estimation of blue-green abundances, special attention has been paid upon this carotenoid. Interestingly, on a basis of biovolume this carotenoid seems to be quite stable independend of different light and nutrient conditions (Kana et al. 1988, Nicklisch \& Woitke 1999), which entices to a direct conversion (eg. Woitke et al. 1996, Schmid et al. 1998). However, one should question crucially, if a direct conversion of physiologically highly influenced components like pigments into biovolume is justified for the specific problem. In the author's opinion, for natural algal assemblages an estimation on basis of chl-a should be preferred. This pre-condition cuts down possible marker pigments to carotenoids which co-vary with chl-a.

\section{Rhodophyta}

In the rhodophyta, only chl-a was detected ; chl-d, differing from chl-a by an oxidized 3-vinyl group, was not found. As most reports of chl-d in the rhodophyta were published without references (Ettl 1980, Kohl \& Nicklisch 1988, Häder 1999, Lee 1999) this might actually hint at a historical, artificial preparatory phenomenon, nowadays unobserved. Isolated reports of chld in the rhodophyta are by Manning \& Strain (1943), Smith \& Benitez (1955), French (1960) and O'hEocha (1971). Sagromsky (1964) observed within three marine taxa the formation of a chl-d-like compound caused by photooxydation. Pigment analyses of Batrachospermum sp. (Stransky \& Hager 1970), Porphyridium aerugineum (Stransky \& Hager 1970) and P. cruentum (Brody \& Emerson 1959, Stransky \& Hager 1970, Wright et al 1991, Jeffrey et al. 1997) did not yield chl-d.

Red algae are characterized by a simple carotenoid pattern (O'Heocha 1971, Bjornland \& Aguilar-Martinez 1976, Palermo et al 1991, Young \& Britton 1993). The dominating of zeaxanthin over lutein, and of B-carotene over B-carotene commonly observed in marine rhodophyta (Goodwin \& Britton 1988) was not found in Batrachospermum moniliforme (Table 5).

\section{Cryptophyta}

Chl-a and chl- $\mathrm{c}_{2}$ were isolated from the pigment extracts. In this study, around $7 \%$ chl- $c_{2}$ per chl-a were 
found, which is in good agreement to other investigations (Mackey et al. $1996: 8-17 \%$; Goericke \& Montoya 1998 : ca. $4 \%$ ). Besides chl-c 2 (Jeffrey 1976, Wright et al 1991), faint traces of chl- $\mathrm{c}_{1}$ were detected, too (Rhodomonas sp.; Kraay et al. 1992).

In the investigated cryptomonads the class-specific xanthophylls alloxanthin and monadoxanthin were discovered, with alloxanthin being the main constituent of the carotenoid fraction (around $26 \%$ per chl-a, Table 5). This result highly corresponds to amounts analyzed from the freshwater species Cryptomonas ovata Ehrenb. (25 \%; Wilhelm et al. 1991, McManus 1995). For marine species, Goericke \& Montoya (1998) found 6 - $13 \%$ in Chroomonas salina (Wislouch) Butcher), Mackey et al. (1996) observed amounts between 4 and $23 \%$. The acetylenic xanthophyll crocoxanthin was not found. According to Goodwin \& Britton (1988) also in this study only acetylenic carotenoids and zeaxanthin were detected, allenic carotenoids are missing. Zeaxanthin, so far, was detected in traces in Cryptomonas ovata only (Pennington et al 1985). Another particularity is the dominance of $\alpha$-carotene over B-carotene (this study, Hager \& Stransky 1970b, Goodwin \& Britton 1988).

\section{Complementary chromatic adaptation}

Although not studied here, the possible role of phycobiliproteins and/or carotenoids in complementary chromatic adaptation is briefly discussed, since pigments involved in this process are only of limited interest for phytoplankton quantification. At the end of the $19^{\text {th }}$ century, Engelmann $(1883 \mathrm{a}, \mathrm{b})$ postulated that the vertical distribution of marine macroalgae is defined by the different depths to which the individual spectral colors of the sunlight penetrate the ocean. Engelmann based this statement on his perception that assimilation is strongest when algae are exposed to light of a spectral color complementary to their own color. His student Gaidukov (1903) deliberately varied the colors of Oscillatoria, cultivating greenish filaments under red illumination and reddish ones by applying green light. Both, Engelmann (1883a, b, 1884) and Gaidukov (1903) established the term «complementary chromatic adaptation». In contrast to Engelmann, Oltmanns (1892), based on his own experiments, postulated, that depth distribution of marine algae is entirely controlled by light intensity. Harder (1923) united both theories, in a way, concluding from his experiments on the cyanoprokaryote Phormidium foveolarum, that both light intensity and spectral quality influence assimilation.
Recent studies of cyanoprokaryota confirm the ability of the blue-greens to adapt to different light qualities by means of phycobiliproteins adhering as phycobilisomes to the thylacoids (Bogorad 1975, Tandeau de Marsac 1977 in Kohl \& Nicklisch 1988, van Liere \& Walsby 1982, Lönneborg et al. 1985, Wood 1985 ; Ojala 1993).

To some extent, chromatic adaptation is also an adaptation to light intensity. Red and white light act as high intensities, whilst green light is interpreted as low intensity illumination (Wyman \& Fay 1986, Kohl \& Nicklisch 1988). Jones \& Myers (1965) reported distinct reduction of the cellular chl-a content in Synechococcus nidulans (Pringsh.) Kom. (formerly Anacystis) when cultured under green illumination. Since levels of phycocyanin and of carotenoids remained almost unchanged, total pigment proportions shifted in favour of the phycobilines.

Complementary chromatic adaptation can also be expected within the rhodophyta as these organisms, contain phycobilisomes, too. In Porphyridium cruentum (Ag.) Näg., chromatic adaptation seems to be triggered by light intensity. At low intensities, cells adapt chromatically, whereas at high light conditions they react differently, protecting the photosynthetic apparatus by evenly supplying both photosystems (Brody \& Emerson 1959). In marine macroalgae chromatic adaptation has not yet been observed (Dring 1981, Ramus \& van der Meer 1983).

Cryptophyta, without phycobiliproteins concentrated in phycobilisomes, exhibit only weak chromatic adaptation (Vesk \& Jeffrey 1977; Ojala 1993).

Complementary chromatic adaptation, as established by Engelmann (1883a,b, 1884) and Gaidukov (1903), makes it necessary for algae to synthesize pigments of a color complementary to the color of the prevailing light. Blue illumination thus would have to result in an increased synthesis of carotenoids (adapted to absorb the blue range of the spectrum). The results specified above indicate an involvement of water-soluble phycobilins concentrated in phycobilisomes thus not affecting carotenoid/chl-a ratios. Since in aquatic ecosystems the light quality changes with depth, this enhances the usefulness of carotenoid/chl-a ratios for algal quantification dramatically.

\section{Acknowledgements}

We are very grateful to our colleagues Norbert Gätz and Elsa Kusel-Fetzmann. Their readiness in assistance and discussions supported this study in many ways. Many thanks also to Thomas Haunold for critical reading and translation. 


\section{References}

Abaychi J.K. \& Riley J.P. 1979. — The determination of phytoplankton pigments by High-Performance Liquid Chromatography. Analyt. Chim. Acta, $107: 1-11$.

Bidigare R.R., Kennicutt M.C. \& Brooks J.M. 1985. — Rapid determination of chlorophylls and their degradation products by high performance liquid chromatography. Limnol. Oceanogr,. 30 (2) : 432-435.

Bjornland T. \& Aguilar-Martinez M. 1976. — Carotenoids in red algae. Phytochemistry, $15: 291-296$.

Bjornland T., Liaaen-Jensen S. \& Throndsden J. 1989. — Carotenoids of the marine chrysophyte Pelagococcus subviridis. Phytochemistry, 28 (12) : 3347-3353.

Bogorad L. 1975. - Phycobiliproteins and complementary chromatic adaptation. Ann. Rev. Plant Physiol., 26 : 369-401.

Britton G. 1988. - Biosynthesis of Carotenoids. Pages 133-182 in Plant pigments. Goodwin T.W. (Ed.). Academic Press, London, San Diego.

Brody M. \& Emerson R. 1959. - The effect of wavelength and intensity of light on the proportion of pigments in Porphyridium cruentum. Amer. J. Bot., $46: 433-440$.

Carpenter E.J., O`Neil J.M., Dawson R., Capone D.G., Siddiqui D.J.A., Orenneberg T., Bergman B. 1993. - The tropical diazotrophic phytoplankter Trichodesmium : biological characteristics of two common species. Mar. Ecol. Prog. Ser., 95 : 295-304.

Cogdell R. 1988. — The function of pigments in chloroplasts. Pages 183-230 in Plant pigments. Goodwin T.W. (Ed.). Academic Press, London, San Diego.

Demmig-Adams B. 1989. - Lichtstreß und Lichtschutz bei Pflanzen. Naturwissenschaften, $76: 262-267$.

Demmig-Adams B. 1990. - Caroteniods and photoprotection in plants : a role for the xanthophyll zeaxanthin. Biochim. Biophys. Acta , $1020: 1-24$

Descy J.-P. \& Métens A. 1996. — Biomass-pigment relationships in potamoplankton. J. Plankton Res., 18 : 1557-1566.

Donabaum K. 1992. — Der Chlorophyll-a Gehalt von Planktonalgen. Diss. Thesis Univ. Vienna, 264 pp.

Dring M.J. 1981. — Chromatic adaptation of photosynthesis in benthic marine algae : An examination of its ecological significance using a theoretical model. Limnol. Oceanogr,. $26: 271-284$.

Engelmann T.W. 1883a. — Farbe und Assimilation I. Bot. Z., 41 : $1-13$

Engelmann T.W. 1883b. — Farbe und Assimilation III. Bot. Z., 41 : 17-29.

Engelmann T.W. 1884. - Untersuchungen über die quantitativen Beziehungen zwischen Absorption des Lichtes und Assimilation in Pflanzenzellen. Bot. Z., $42: 81-94$.

Ettl H. 1980. - Grundriß der allgemeinen Algologie. G. Fischer, Stuttgart, 549 pp.

Fiksdahl A., Foss P. \& Liaaen-Jensen S. 1983. — Carotenoids of blue-green algae - 11. Carotenoids of chromatically-adapted cyanobacteria. Comp. Biochem. Physiol., 76 B (3) : 599-601.

Foppen F.H. 1971. - Tables for the identification of carotenoid pigments. Chrom. Rev., 14 : 133-298.

French C.S. 1960. - The chlorophylls in vivo and in vitro. Pages 252-297 in Handbuch der Pflanzenphysiologie, Band V/1. Ruhland W. (Ed.). Springer-Verlag, Berlin.

Gaidukov N. 1903. - Weitere Untersuchungen über den Einfluss farbigen Lichtes auf die Färbung der Oscillarien. Ber. Dt. Bot. Ges., 21 : 484-493.

Gätz N. 1990. — Untersuchungen zur Stickstoff- und Phosphor-Versorgung von Microcystis aeruginosa Kütz. und Microcystis flosaquae (Wittr.) Kirchn. im Neusiedler See. Wiss. Arb. Burgenland, $82: 51-79$.
Gieskes W.W.C. \& Kraay G.W. 1983. — Dominance of Cryptophyceae during the phytoplankton spring bloom in the central North Sea detected by HPLC analysis of pigments. Mar. Biol., 75 : 179-185.

Gieskes W.W.C. \& Kraay G.W. 1986a. — Analysis of phytoplankton pigments by HPLC before, during and after mass occurence of the microflagellate Corymbellus aureus during the spring bloom in the open northern North Sea in 1983. Mar. Biol., 92 : 45-52.

Gieskes W.W.C. \& Kraay G.W. 1986b. - Floristic and physiological differences between the shallow and the deep nanophytoplankton community in the euphotic zone of the open tropical Atlantic revealed by HPLC analysis of pigments. Mar. Biol., 91 : 576-576.

Glazer A.N. 1982. - Phycobilisomes : Structure and dynamics. Ann. Rev. Microbiol., 36 : 173-198.

Glazer A.N. 1984. - Phycobilisome, a macromolecular complex optimized for light energy transfer. Biochim. Biophys. Acta, 768 29-51.

Goericke R. 1998. — Response of phytoplankton community structure and taxon-specific growth rates to seasonally varying physical forcing in the Sargasso Sea of Bermuda. Limnol. Oceanogr, $43:$ 921-935.

Goericke R. \& Montoya J.P. 1998. — Estimating the contribution of microalgal taxa to chlorophyll a in the field - variations of pigment ratios under nutrient - and light-limited growth. Mar. Ecol. Prog. Ser, $169:$ 97-112.

Goodwin T.W. \& Britton G. 1988. — Distribution and analysis of carotenoids. Pages 61-132 in Plant pigments. Goodwin, T.W. (Ed.). Academic Press, London, San Diego.

Guillard R.R.L., Murphy L.S., Foss P. \& Liaaen-Jensen S. 1985. Synechococcus spp. as likely zeaxanthin-dominant ultraphytoplankton in the North Atlantic. Limnol. Oceanogr., $30: 412-414$.

Häder D.-P. 1999. — Photosynthese. Thieme Verlag. 269 pp.

Hager A. \& Stransky H. 1970a. — Das Carotinoidmuster und die Verbreitung des lichtinduzierten Xanthophyllcyclus in verschiedenen Algenklassen III. Grünalgen. Arch. Mikrobiol., 72 : 68-83.

Hager A. \& Stransky H. 1970b. - Das Carotinoidmuster und die Verbreitung des lichtinduzierten Xanthophyllcyclus in verschiedenen Algenklassen V. Einzelne Vertreter der Cryptophyceae, Euglenophyceae, Bacillariophyceae, Chrysophyceae und Phaeophyceae. Arch. Mikrobiol., 73 : 77-89.

Hallegraeff G.M. 1981. — Seasonal study of phytoplankton pigments and species at a coastal station off Sydney : importance of diatoms and the nanoplankton. Mar. Biol., 61 : 107-118.

Hallegraeff G.M. \& Jeffrey S.W. 1985. - Description of new chlorophyll a alteration products in marine phytoplankton. Deep Sea Research, 32 : 697-705.

Harder R. 1923. - Über die Bedeutung von Lichtintensitt und Wellenlänge für die Assimilation farbiger Algen. Zeitschr.f. Bot., 15 : 306-355.

Healey F.P. 1968. - The carotenoids of four blue-green algae. $J$. Phycol., 4 : 126-129.

Hertzberg S., Liaaen-Jensen S. \& Siegelman H.W. 1971. — The carotenoids of blue - green algae. Phytochemistry, $10: 3121-3127$.

Hiller R.G., Anderson J.M. \& Larkum W.D. 1991. — The chlorophyll-protein complexes of algae : Pages 529-547 in Chlorophylls. Scheer H. (Ed.). Bocaraton : crc-Press, Boston.

Hiraoka M., Obata S., Ohno M. 1998. — Pigment content of the reproductive cells of Ulva pertusa (Ulvales, Ulvophyceae) : evidence of anisogamy. Phycologia, $37: 222-226$.

Hynninen P.H. \& Assandri S. 1973. - Chlorophylls II. Allomerization of chlorophylls a and b. Acta Chem. Scand., 27 : 1478-1486. 
Jacobsen T.R. \& Rai H. 1990. — Comparison of spectrophotometric, fluorometric and high performance liquid chromatography methods for determination of chlorophyll-a in aquatic samples : effects of solvents and extraction procedures. Int. Rev. Ges. Hydrobiol., $75: 207-217$.

Jeffrey S.W. 1976. - The occurence of chlorophyll $c_{1}$ and $c_{2}$ in algae. J. Phycol. $12: 349-354$

Jeffrey S.W., Mantoura R.F.C. \& Wright S.W. 1997. — Phytoplankton pigments in oceanography. Unesco Publishing, France : $661 \mathrm{pp}$.

Jeffrey S.W. \& Wright S.W. 1987. — A new spectrally distinct component in preparations of chlorophyll c from the microalga Emiliana huxlei (Prymnesiophyceae). Biochim. Biophys. Acta, 894 : 180-188.

Jones L.W. \& Myers J. 1965. — Pigment variations in Anacystis nidulans induced by light of selected wavelengths. J. Phycol., 1 : 7-14.

Kana T.M., Glibert P.M., Goericke R. \& Welschmeyer N.A. Zeaxanthin and B-carotene in Synechococcus WH7803 respond differently to irradiance. Limnol. Oceanogr. 33 : 1623-1627.

Klein B. \& Sournia A. 1987. - A daily study of the diatom spring bloom at Roscoff (France) in 1985. II. Phytoplankton pigment composition studied by HPLC analysis. Mar. Ecol. Prog. Ser., $37: 265-275$.

Kohata K. \& Watanabe M. 1988. - Diel changes in the composition of photosynthetic pigments ans cellular carbon and nitrogen in Chattonella antiqua (Raphidophyceae). J. Phycol., 24 : 58-66.

Kohata K. \& Watanabe M. 1989. — Diel changes in the composition of photosynthetic pigments ans cellular carbon and nitrogen in Pyraminomonas parkarae (Prasinophyceae). J. Phycol., 25 : 377-385.

Kohata K. \& Watanabe M. 1991. - Highly sensitive determination of photosynthetic pigments in marine in situ samples by high-performance liquid chromatography. J. Chromatogr., 558 : 131-140.

Kohl J.-G. \& Nicklisch A. 1988. — Ökophysiologie der Algen. Akademie-Verlag, Berlin : 253 pp.

Kraay G.W., Zapata M. \& Veldhuis M.J.W. 1992. — Separation of chlorophylls c1, c2, and c3 of marine phytoplankton by reversed phase - C18 - high - performance liquid chromatography. J. Phycol., $28: 708-712$.

Kusel-Fetzmann E. \& Schagerl M. 1992. Verzeichnis der Sammlung von Algenkulturen an der Abteilung Hydrobotanik am Institut für Pflanzenphysiologie der Universität Wien. Phyton, 32 (2) : 209-234.

Latasa M., Landry M.R., Schlüter L. \& Bidigare R.R. 1997. — Pigment-specific growth and grazing rates of phytoplankton in the central equatorial Pacific. Limnol. Oceanogr,. 42 : 289-298.

Lee R.E. 1999. - Phycology. Cambridge University Press, $3^{r d}$ Ed., $614 \mathrm{pp}$.

Liaaen-Jensen S. 1978. - Marine carotenoids. In : Scheuer P.J. (Ed.) Marine Natural Products : Chemical and Biological Perspectives $2: 1-73$.

Lönneborg A., Lind L.K., Kalla S.R., Gustavsson P. \& Öquist G. 1985. - Acclimation processes in the light-harvesting system of the cyanobacterium Anacystis nidulans following a light shift from white to red light. Plant. Physiol., 78 : 110-114.

Mackey M.D., Mackey D.J., Higgins H.W. \& Wright S.W. 1996. CHEMTAX - a program for estimating class abundances from chemical markers : application to HPLC measurements of phytoplankton. Mar. Ecol. Prog. Ser., 144 : 265-283.

Manning W.M. \& Strain H.H. 1943. - Chlorophyll D, a green pigment of red algae. J. Biol. Chemistry, $151: 1-19$.
Mantoura R.F.C. \& Llewellyn C.A. 1983. — The rapid determination of algal chlorophyll and carotenoid pigments and their breakdown products in natural waters by reverse - phase high - performance liquid chromatography. Analyt. Chim. Acta, 151 : 297-314.

McManus G.B. 1995. — Phytoplankton abundance and pigment changes during simulated in situ dilution experiments in estuarine waters : possible artifacts caused by algal light adaptation. $J$. Plankton Res., 17 : 1705-1716.

Meyer V. 1999. — Praxis der Hochleistungsflüssigchromatographie (8. überarbeitete Auflage). Verlag Diesterweg/Salle/Sauerländer, Frankfurt am Main, 293pp.

Meyer-Harms B., Pollehne F. 1998. - Alloxanthin in Dinophysis norvegica (Dinophysiales, Dinophyceae) from the Baltic Sea. $J$. Phycol., 34 : 280-285.

Millie D.F., Ingram D.A. \& Dionigi C.P. 1990. — Pigment and photosynthetic responses of Oscillatoria agardhii (Cyanophyta) to photon flux density and spectral quality. J. Phycol., 26 : 660-666.

Nicklisch A. \& Wiotke P. 1999. - Pigment content of selected planktonic algae in response to simulated natural light fluctuations and a short photoperiod. Internat. Rev. Hydrobiol., 84 : 479-495.

Nusch E.A. 1980. - Comparison of different methods for chlorophyll and phaeopigment determination. Arch. Hydrobiol. Beih. Ergebn. Limnol., 23 : 944-951.

O'hEocha C. 1971. - Pigments of the red algae. Oceanogr. Mar. Biol. Ann. Rev, , 9: 61-82.

Ojala A. 1993. - The influence of light quality an growth and phycobiliprotein chlorophyll-a fluorescence quotients of some species of freshwater algae in culture. Phycologia, $32: 22-28$.

Oltmanns F. 1892. - Über die Kultur und Lebensbedingungen der Meeresalgen. Jahrb. wiss. Bot., 23 : 349-440.

Otsuki A., Watanabe M.M. \& Sugahara K. 1987. — Chlorophyll pigments in methanol extracts from ten axenic cultured diatoms and three greenalgae as determined by reverse phase HPLC with fluorimetric detection. J. Phycol., 23 : 406-414.

Palermo J.A., Gros E.G. \& Seldes A.M. 1991. — Carotenoids from three red algae of the Corallinaceae. Phytochemistry, 30 (9) : 2983-2986.

Pennington F.C., Haxo F.T., Borch G. \& Liaaen-Jensen S. 1985. Carotenoids of Cryptophyceae. Biochem. Syst. Ecol., 13 (3) : 215-219.

Ramus J. \& van der Meer J.P. 1983. - A physiological test of the theory of complementary chromatic adaptation. I. color mutants of a red seweed. J. Phycol., $19: 86-91$.

Resch C.M. \& Gibson J. 1983. — Isolation of the carotenoid-containing cell wall of three unicellular cyanobacteria. J. Bacteriol., $155: 345-350$.

Rowan K.S. 1989. - Photosynthetic pigments of algae. Cambridge Unviersity Press, 334 pp.

Roy S. 1989. - HPLC-measured chlorophyll-type pigments during a phytoplankton spring bloom in Bedford Basin (Canada). Mar. Ecol. Prog. Ser., 55 : 279-290.

Roy S., Chanut J.P., Gosselin M. \& Sime-Ngando T. 1996. — Characterization of phytoplankton communities in the lower St. Lawrence Estuary using HPLC-detected pigments and cell microscopy. Mar. Ecol. Prog. Ser., 142 : 55-73.

Rücker J. Kohl J.-G. \& Kaiser K. 1995. — Responses of carotenoids and chlorophylls to variations of growth-limiting factors in three filamentous blue-green algae. Arch. Hydrobiol./Algol. Stud., 77 : 51-65.

Sagromsky H. 1964. - Ist Chlorophyll d der Rotalgen ein Umwandlungsprodukt von Chlorophyll a?. Ber. Dtsch. Bot. Ges., 77 : 323-326. 
Sartory D.P. 1985. - The determination of algal chlorophyllous pigments by high performance liquid chromatography and spectrophotometry. Water Res. , 19 : 605-610.

Schmid H., Bauer F. \& Stich B. 1998. - Determination of algal biomass with HPLC pigment analysis from lakes of different trophic state in comparison to microscopically measured biomass. $J$. Plankton Res., 20 : 1651-1661.

Schofied O., Evens T.J. \& Millie D.F. 1998. — Photosystem II quantum yields and xanthophyll-cycle pigment of the macroalga Sargassum natans (Phaeophyceae) : responses under natural sunlight. J. Phycol., 34 : 104-112.

Scholz B. \& Ballschmiter K. 1981. — Preparation and reversed-phased high-performance liquid chromatography of chlorophylls. $J$. Chromatogr., 208 : 148-155.

Senge M. \& Senger H. 1991. - Adaptation of the photosynthetic apparatus of Chlorella and Ankistrodesmus to blue and red light. Bot. Acta, 104 : 139-143.

Shioi Y., Doi M. \& Sasa T. 1984. - Separation of non - esterified chlorophylls by ion - supression high performance liquid chromatographie. J. Chromatogr., 298 : 141-149.

Shioi Y., Fukae R. \& Sasa T. 1983. - Chlorophyll analysis by highperformance liquid chromatography. Biochim. Biophys. Acta, $722: 72-79$.

Siefermann-Harms D. 1985. - Carotenoids in photosynthesis. I. Location in photosynthetic membranes and light-harvesting function. Biochim. Biophys. Acta, $811: 325-355$.

Smith H. C. \& Benitez A. 1955. - Chlorophylls : analysis in plant materials. Pages 142-196 in Moderne Methoden der Pflanzenanalyse. Paech K. \& Tracey M.V. (Eds.). Springer Verlag, Wien IV.

Steinman A.D., Havens K.E., Louda J.W., Winfree N.M. \& Baker E.W. 1998. - Characterization of the photoautotrophic algal and bacterial communities in a large, shallow, subtropical lake using HPLC-PDA based pigment analysis. Can. J. Fish. Aquat. Sci., $55: 206-219$.

Stransky H. \& Hager A. 1970. - Das Carotinoidmuster und die Verbreitung des lichtinduzierten Xanthophyllzyklus in verschiedenen Algenklassen IV. Cyanophyceae und Rhodophyceae. Arch. Mikrobiol., $72:$ 89-96.

Strom S.L. \& Welschmeyer N.A. 1991. — Pigment-specific rates of phytoplankton growth and microzooplankton grazing in the open subarctic Pacific Ocean. Limnol. Oceanogr. 1991 : 50-63.

Suzuki R. \& Fujita Y. 1986. - Chlorophyll decomposition in Skeletonema costatum : a problem for chlorophyll determination of water samples. Mar. Ecol. Prog. Ser., 28 : 81-85.

Tandeau de Marsac N.T. 1977. - Occurence and nature of chromatic adaptation in cyanobacteria. J. Bacteriol., $130: 82-91$.

Tester P.A., Geesey M.E., Guo C., Paerl H.W. \& Millie D.F. 1995. Evaluating phytoplankton dynamics in the Newport River estuary (North Caroling, USA) by HPLC-derived pigment profiles. Mar. Ecol. Prog. Ser., 124 : 237-245.

Unger K.K. (Ed.) 1989. — Handbuch der HPLC. Teil 1 : Leitfaden für Anfänger und Praktiker. GIT-Verlag, Darmstadt : $359 \mathrm{pp}$.
Van den Hoek C., Jahns H.M., Mann D.G. 1993. — Algen. Thieme Verlag, $411 \mathrm{pp}$.

Van Liere L. \& Walsby A.E. 1982. — Interactions of cyanobacteria with light. Pages 10-45 in The biology of Cyanobacteria : Bot. Monographs 19. Carr N.G. \& Whitton B.A (Eds). Oxford : Blackwell Sci. Publ.

Veldhuis M.J.W. \& Kraay G.W. 1990. — Vertical distribution and pigment composition of a picoplanctonic prochlorophyte in the subtropical North Atlantic : a combined study of HPLC-analysis of pigments and flow cytometry. Mar. Ecol. Prog. Ser., 68 : 121-127.

Vesk M. \& Jeffrey S.W. 1977. — Effect of blue-green light on photosynthetic pigments and chloroplast structure in unicellular marine algae from six classes. J. Phycol., $13: 280-288$.

Weber A. \& Wettern M. 1980. — Some remarks on the usefulness of algal carotenoids as chemotaxonomic markers. Pages 104-116 in Pigments in plants. Czygan F.-C. (Ed.). G.Fischer, Stuttgart, New York.

Wilhelm C., Rudolph I. \& Renner W. 1991. - A quantitative method based on HPLC-aided pigment analysis to monitor structure and dynamics of the phytoplankton assemblage - A study from Lake Meerfelder Maar (Eifel, Germany). Arch. Hydrobiol., 123 : 21-35.

Woitke P., Schiwietz T., Teubner K. \& Kohl J.G. 1996. - Annual profiles of photosynthetic pigments in four freshwater lakes in relation to phytoplankton counts as well as to nutrient data. Arch. Hydrobiol., 137 : 363-384.

Wood A.M. 1985. - Adaptation of photosynthetic apparatus of marine ultraphytoplankton to natural light fields. Nature 316 (18) : 253-255.

Wright S.W., Jeffrey S.W., Mantoura R.F.C., Llewellyn C.A., Bjornland T., Repeta D. \& Welschmeyer N.A. 1991. - Improved HPLC method for the analysis of chlorophylls and carotenoids from marine phytoplankton. Mar. Ecol. Prog. Ser., 77 : 183-196.

Wright S.W. \& Shearer J.D. 1984. - Rapid extraction and High performance liquid chromatography of chlorophylls and carotenoids from marine phytoplankton. J. Chromatogr., 294 : 281-295.

Wright S.W., Thomas D.P., Marchant H.J., Higgins H.W., Mackey M.D. \& Mackey D.J. 1996. - Analysis of phytoplankton of the australian sector of the southern ocean : comparisons of microscopy and size frequency data with interpretations of pigment HPLC data using the 'CHEMTAX'matrix factorisation program. Mar. Ecol. Prog. Ser., 144 : 285-298.

Wyman M. \& Fay P. 1986. - Underwater light climate and the growth and pigmentation of planktonic blue-green algae (Cyanobacteria). II. The influence of light quality. Proc. R. Soc. Lond., 227 (B) : 381-393.

Young A. \& Britton G. 1993. - Carotenoids in Photosynthesis. Chapman \& Hall, 498pp.

Zapata M. \& Garrido J.L. 1991. - Influence of injection conditions in reversed-phase high performance liquid chromatography of chlorophylls and carotenoids. Chromatographia, 31 : 589-594. 